\title{
The Comparative Impact of Autonomy and Critical Thinking on EFL Learners' Writing Achievement
}

\author{
Behdokht Mall-Amiri \\ Islamic Azad University at Central Tehran, Iran \\ Fatemeh Sheikhy \\ Islamic Azad University at Central Tehran, Iran
}

\begin{abstract}
The present study was an attempt to compare the effect of critical thinking techniques, and autonomy techniques on EFL learners' writing achievement. To fulfill the purpose of the study, 74 participants of a total number of $\mathbf{1 0 0}$ learners at intermediate level who were studying in Kish Way Language School in Karaj were selected by means of a piloted PET. At the next stage, the 74 participants were divided into two experimental groups randomly so that one group would receive critical thinking techniques and the other autonomy practice as the two treatments. Prior to the start of the treatments, the scores of the writing section of the PET obtained by both groups were compared to make sure that the learners were homogeneous regarding their writing ability at the outset. At the end of the instructional period, both groups were given a writing posttest, and the comparison of their means revealed that the difference between the two groups' writing posttest scores was non-significant, hence the null hypothesis failed to be rejected, implying that both groups benefited the treatments equally in their writing improvement.
\end{abstract}

Index Terms - autonomy, critical thinking, writing

\section{INTRODUCTION}

Education and learning need some special techniques to indulge learners more deeply and efficiently-techniques that involve learners to become more independent and at the same time more thoughtful. It is a rather recent issue that educators are focusing their attention to critical thinking and autonomy on different skills, although "critical thinking is as integral part of education and training in schools of foreign and second language instruction" (Shangarffam \& Mamipour, 2011, p.1), and so is autonomy.

Writing is one of the most effective ways of conveying ideas and thoughts to others, so learning to write is important because without it education, and more important, communications will be defective and will face problems.

According to Pemberton and Nix (2012), writing, autonomy, and critical thinking seem to be linked to each other, and proficiency in writing can be a sign of students' autonomy, critical thinking, and reasoning skills on the other hand. Critical thinking and autonomy are both considered desirable educational goals. Raya, Lamb, and Vieira (2007), mention that "The competence to think critically is coextensive with the notion of autonomy and self-sufficiency" (p.43). And in the same way, Little (1991) explains autonomy as an ability "for detachment, critical reflection, decision making, and independent action" (p.4). Therefore, it is important that teachers help students develop exploring ways for autonomy and critical thinking (Pemberton \& Nix, 2012). Consequently, it seems that teaching learners to become autonomous and at the same time critical thinkers is probably a vital factor in their progress.

\section{A. Autonomy}

In the studies did during the last decades, autonomy concept has been challenged by a number of writers who try to show its relation to language teaching and learning in innovative ways. According to Benson (2001) autonomy is considered not only for individual's life, but also it is too important in social matters that influences our social and collective lives.

Benson (2001) stresses that a lot of students like to have freedom in language learning, and they like to control their own learning. Several writers published books with sections on autonomy, 'including Hedge (2000), Harmer (2001), Kumaravadivelu (2003) on teaching methodology, Nation (2001) on vocabulary, and Thornbury (2005) on speaking' (Benson 2001, p.27).

During the last decade, increased attention has been paid to learners' autonomy, because autonomy is considered as a technique that makes learners learn more about themselves and what they like, what they do not, and how they can be more effective by themselves and not by the help of others (Balçıkanl, 2010).

In the past, teachers had the main role in classrooms, and students had to obey whatever teachers asked them to do. In fact, teachers had active roles and they were the authorities in classrooms, while learners had passive roles and they 
were completely obedient, dependent on their teachers in the process of language learning. As a result, learners lacked initiative in the process of language learning, and they could not do much for their own learning.

While according to WU Li-li (2008), at the present time, because of communication-oriented way of language teaching the traditional teaching has been substituted by the learner-centered classes, and the learner-centered approach has created the concept of learner autonomy. "A common argument for justifying learner autonomy both in general education and language learning is that autonomous learners become highly motivated and the autonomy leads to better and more effective work. That is, an extremely motivated learner is more initiative and creative in learning; consequently, they will make the classroom instruction more useful" (Bagheri \& Aeen, 2011).

\section{B. Critical Thinking}

At the present time, producing students who are autonomous, and critical thinker is a great necessity for the society, because of the great changes in academic requirements (Ming \& Alias, 2003), so many recent studies focus on the growing interest in autonomy, critical thinking, and their effects on language learning. "Criticality and learner autonomy are both widely seen as desirable educational goals, and often understood as independent or even mutually indispensable attributes" (Nix \& Pemberton, 2012). According to Lamb, Raya, and Vieira (2007), "The competence to think critically is coextensive with the notion of autonomy" (p.43).

According to Chaffee (2009), thinking is considered as an important process in life, and it helps people in various issues such as solving their problems, achieving their goals, and making decisions. In the same way, Santrock (2008), believes that thinking has different functions such as reasoning, thinking critically, making decisions, and solving problems. As Chaffee (2009) mentions, the most important purpose of critical thinking is to make "more intelligent decisions", and a critical thinker is a person who can recognize the outside world, make intelligent judgments, and think about "important ideas" (p.43). Also Paul and Elder (2006), believe that critical thinkers try to solve complicated problems in a variety of forms by asking questions, gathering relevant information, and communicating effectively.

In the past, teaching was considered as only presenting knowledge and information to students by the teachers, but during years teachers found it of no effective use in their students' progress. Teachers came to the point that the students need thinking specially critical thinking throughout their learning process. "Thinking may be defined as a pattern of behavior in which we make use of internal representations of things and events for the solution of some specific, purposeful problems" (Mangel, 2005, p.356). In the same way, the concept of critical thinking means a kind of challenging thinking process in which leads the person to better understanding. Halpern (1996) viewed critical thinking from two perspectives which are philosophy and psychology. Philosophers have focused on the nature and quality of the products of critical thinking, while psychologists have noticed the process of cognition, the components, and operations that are used to address academic and practical problems.

\section{Writing}

Nowadays, learning a foreign or second language is not only completely usual, but also essential for everyone, and by learning other languages, people can extend the realm of their communication through speaking or writing. Increasingly, the amount of communication through writing has increased drastically by the use of e-mails and text messages. As a result, writing is not considered anymore as a skill to communicate formally, but it is the skill that learners need to be proficient at more than before because of the need of the new systems of communication (Marashi \& Jafari pur, 2012).

Writing is considered as one of the most difficult skills in second/foreign language learning, and the important point is that it is not considered as something usual, but as an essential part of nowadays life due to the expansion of different forms of communication through writing such as messages, e-mails, letters, and etc. "The difficulty lies not only on generating and organizing ideas, but also in translating these ideas into readable texts" (Marashi \& Jafari, 2012). Among the four language skills, creating a coherent and well-written piece of writing has been the most difficult task to do in both the first and the second language, and foreign language learners usually find writing a difficult and challenging task. One important reason that students have great problems in writing is that they usually do not receive suitable instruction for this skill, and they do not know how to write, because of that Richards (1990) states that the nature and importance of writing have been undervalued in language teaching.

It is believed that language is the most effective vehicle for performing the process of thinking, so Mangel (2005) has placed language under the element of thought and thinking. Accordingly, Halpern (1996) mentioned that language is a medium to express one's thought, and believed that comprehension is the most critical reason for using language, so all language skills such as writing involve comprehension, and thinking critically.

Writing is considered as a means of recording ideas, information, and knowledge. At the same time, students can recheck, develop, and create new thought. Al-Hazmi (2006), states that writing is a necessary component for improving and developing critical thinking skill, because it causes reflecting, correcting, editing, and spending more time comparing to oral skill. She believes that teaching writing through effective and suitable techniques can improve their writing skill greatly, and specially taking care about process rather than product approach can increase autonomy and criticality among them. During process writing, students usually reflect on their writing to convey their ideas and feelings more efficiently about their knowledge and information, and this simultaneously leads to the increase of critical 
thinking. Accordingly, Al-Hazmi (2006), believes that recently the focus of teachers and researchers is on process approach for EFL writing teaching.

\section{METHOD}

\section{A. Participants}

The participants of this study were 74 intermediate female students with the age range of 22-35 studying English at Kish Way Language School in Karaj who were chosen among 100 intermediate students based on their performance in a pre-piloted Preliminary English Test (PET). The 100 students were chosen non-randomly out of about 220 students.

\section{B. Instrumentation and Materials}

In order to fulfill the purpose of the study, the following instruments were employed:

\section{Preliminary English Test for Homogenization}

In order to follow the purpose of the study, a Preliminary English Test (PET) was conducted to select 60 participants from 100; however, after administering the PET, 74 participants were selected due to the result showing that 74 students' scores fell one standard deviation above and below the sample mean; therefore, the researcher carried out the research considering all the 74 students as the participants. This test was used to homogenize the participants based on their English language proficiency. The PET test was by Cambridge ESOL, and it consisted of three parts containing questions for four skills including reading and writing as the first part, listening the second part, and speaking as the third part of the test. Only the first two sections comprising reading, writing and listening parts were administered due to time restrictions and reluctance of the participants to undergo the speaking test.

The PET, as used in this study, contained three papers, the first paper measured reading skill with five parts and thirty five questions which consisted of twenty multiple choice, five matching, and ten true/false questions with twenty five percent of the total mark of the test. The second paper tested the writing skill with three parts and seven questions which contained five fill - in - the - blank questions and two essays (descriptive) with twenty five percent of the total mark of the test. The time allocated for these two parts/skills was an hour and thirty minutes. The second part measured listening skill with four parts and twenty five questions which consisted of thirteen multiple choices, six fill - in - the - blanks and yes/no questions with twenty five percent mark of the total with thirty five minutes time (including six minutes transfer time).

The researcher's colleague helped her as another rater for writing of the PET. The two raters used the Cambridge criteria sections that was provided as the rating criterion.

It is worth mentioning that before the main administration, the test was piloted among 30 intermediate students with similar characteristics to the main participants.

\section{Writing Posttest}

At the end of the semester, the researcher administered the writing section of another PET test (not the same version as the first PET that was conducted for homogenization) as a post-test to the two groups and compared the performance of the them in order to reveal which of the treatments, autonomy or critical thinking, had a greater impact on intermediate learners' writing achievement, thus to test the null hypothesis of the study. The writing section of the PET that was used as a post-test consisted of three parts with fill in the blanks and writing essays (descriptive such as writing a letter to a friend, or writing a story for your teacher) with about fifty minutes time allocation which consisted twenty five marks. The scores were given by two raters while they used the same rating scale as the one they used for the first PET, and finally the average score given by them to each participant was considered as the final score of each participant.

\section{Writing Scale/Rubric}

The scale that was considered by both raters for both PET tests, was the General Mark Scheme for Writing of the mentioned PET tests by Cambridge that considered the content, organization, cohesion, coherence, format, range, appropriacy, and mechanical accuracy of participants' pieces of writing. The writing subtest of PET consists of three tasks, 1) fill-in-the blanks, 2) short paragraph writing with a picture prompt, and 3) long paragraph writing around 100 words. The scores were given between the range of 0-5 for the first two witting tasks, and between the range of 0-15 for the third writing task. Thus, the total score for this section was 25. Also word choice, dictation, and sentence structures were taken into account by both raters.

\section{Textbook}

The main textbook that was used at this level was "Interchange 3" third edition by Richards, Hull and Proctor (2005) that was used as their course book. The mentioned textbook consists of different parts with emphasis on all four skills (listening, speaking, reading, and writing), and also sub-skills (pronunciation, grammar, and vocabulary). During this study, unites 12-16 were taught according to the course objectives. It has a workbook too that was practiced by the learners and checked by the researcher every session, and a CD that was played for parts such as conversation, listening parts, pronunciation, and grammar. Also the participants in both groups took the same mid-term (on eleventh session), and final exam (on nineteenth session) as the course objective.

\section{Materials for Practicing Autonomy and Critical Thinking}


Materials for practicing these two techniques were some parts of the newspapers IRAN NEWS and TEHRAN TIMES. Some story books suitable for intermediate level such as The house by the sea and The fox were used as well. It is to be noted, however, that pursuing the goals of autonomous learning, the autonomy group chose the materials and topics themselves.

\section{Procedure}

Initially, the researcher piloted the Preliminary English Test (PET) on 30 intermediate students with similar characteristics to the target sample before administering it to the target participants. Afterwards, the reliability and item analyses were checked. At the next step, 100 students who were studying English in Kish Way Language School in Karaj and attended the classes which were held three days a week for a total period of 6 weeks (18 sessions, each session 105 minutes, and they took the same mid-term exam on eleventh session, and final exam on nineteenth session), were chosen randomly from among the total 220 of the learners in that institute. A sample of Preliminary English Test (PET) was administered to the 100 learners to draw a homogenized sample from them. Afterwards, 74 students whose scores fell one standard deviation above and below the mean were selected as the target participants of the study. Next, the participants were randomly divided into two experimental groups, one as the autonomy group and the other as the critical thinking group.

As the next step, the participants' scores in the writing part of the PET were analyzed further to see if the two groups were the same regarding their writing ability prior to the treatments. Thus, an independent samples t-test was used for making sure that there was no significant difference between the writing ability of the two groups. In order to avoid the subjectivity in the rating of participants' writings, two raters (researcher and one of her experienced colleagues) scored the writings using the same rating scale in this study. The final score of each participant was provided by the average score given by the researcher and her colleague after making sure that the inter-rater reliability was high.

During the semesters, all the 74 participants underwent the same procedure of teaching in terms of the skills of listening, speaking, and reading. They attended the classes which were held three days a week for a total period of 6 weeks (18 sessions, each session 105 minutes, and they took the same mid-term exam on eleventh session, and final exam on nineteenth session). They were also assigned the same homework even in their writing instruction (in addition to writing in the class, they were assigned to write one paragraph as their homework each week).

The difference was in the two treatments of this study; the two procedures that the researcher adopted to teach the writing component of the course. In one of these two experimental groups, the researcher used autonomy techniques during the course as treatment while in the other group, she taught the materials using critical thinking techniques as treatment (although both groups received the same instruction as the course objectives). The researcher followed the same mentioned procedure during the semesters in all eighteen sessions for both groups. These two different techniques for teaching writing are explained in detail below.

\section{Practicing Critical Thinking Techniques}

In the critical thinking group, the critical thinking techniques of debating, reasoning, problem solving, classifying, clarifying, and analyzing media were employed during the term. Each of these two techniques were practiced in 6 sessions of the course. The researcher spent some minutes to familiarize the students with each of these concepts. To this end as an example, she asked the participants to write a paragraph about their favorite lifestyle, and she asked them to have some drafts in order to be able to add or correct some points whenever it was needed. By preparing some drafts at first, the students were able to add or remove some pieces of information after reflection.

The researcher tried to focus the process of writing, and emphasized on creativity and critical thinking in the class. Process was focused because it is an important point in thinking critically; in addition, drafting is the prerequisite for critical thinking because some parts may needed editing after critical thinking. Emphasizing on process approach by the researcher for writing led the students to reflect, edit, and evaluate their writings. The researcher asked the participants to think creatively about facing a problem, finding solutions, and having unique as well as multiple perspectives; that is, she asked them to think about different solutions for a problem and not just focusing on one solution. She asked the participants to write about a variety of topics due to the nature of critical thinking, topics such as the ideal society, the goal of academic education, and the advantages and disadvantages of living abroad.

As another example, the researcher asked the participants to think of multiple sides of an issue for teaching the technique of debate and she asked them not to interact only on the details of issues, but also with one another and find the relationship among ideas. For this purpose, she asked them to define and elaborate a problem again and again considering all the possible solutions, and see multiple perspectives (not only the easiest, fixed solution), and she asked them to think about the possible relations among ideas and solutions in order to come up with the best result. For analyzing media, she brought some articles of the newspapers or magazines to the class, and she asked them to raise some questions themselves, develop a checklist, and then analyze the questions in media, and sometimes she raised some questions to motivate them for practicing and learning critical thinking. Some of the questions were: who is the author? Why did s/he write it? Do you agree with the ideas that are presented in the articles? How do you feel personally about them? Do you think that the ideas and facts are accurate? Also the participants were asked to think about evaluation as an important factor in critical thinking, and as a process for drafting and editing their ideas and writing. Totally, they were asked to write eighteen pieces of writing in the class (one writing in each session), and six pieces of writing as their homework at home (one writing per week) during the research. Some of the writing topics 
were their dream house, plans for next holiday, their life future goals, ideal parents, a good job, and the features of success. The researcher spent about 30 minutes for practicing critical thinking techniques at the beginning of each session.

\section{Practicing Autonomy Techniques}

During the study and as a general process that was considered for all 37 students in autonomy group, the researcher asked the students to bring interesting topics, pieces of news, photos and pictures to class, and share their own ideas with their classmates and also present their own ideas about them. Each of them was asked to choose a topic that she was interested in and give a lecture on that topic in the class, and each of them was asked to rewrite a story or a piece of news briefly on a piece of paper, ask her peers in the group to correct it, score it, and at the end give it to the teacher. In this regard, they understood that they were responsible for their own learning and what they learn according to topics, news, analyzing pictures, and how they learn. The researcher encouraged students to look for interesting materials such as: reading English books, newspapers, magazines, surfing the internet, participating in competitions, and finding pen pals on the internet in order to foster autonomy in them. Totally, the researcher had less role in controlling and having power in the class, and she mostly acted as a monitor. On the other hand, students were the ones that took responsibility and control for their own learning, and tried to become more independent and develop autonomy.

The autonomy group was divided into twelve sub-groups - each sub-group consisted of three students. They worked in their groups and decided themselves on writing a composition about their favorite topics, elaborating some illustrations, writing a story for some pictures, describing an interesting recent event, rewriting a story, and retelling a piece of recent news. Each of these two techniques were practiced in 6 sessions of the course. They had five minutes to choose on what they wanted to write about, and fifteen minutes to write about it. After that, they had another ten minutes to work in groups and check all items in each other's papers and do peer correction regarding word choice, sentence structure, dictation, punctuation, mechanical accuracy, cohesion, coherence, and content of the papers. Whenever they encountered problems in their writing, they tried to solve it by the help of each other; therefore, this activity caused the increase of collaborative learning which improved autonomy and independence in participants. Collaborative activities and group works of learners help them to become more independent and autonomous, and the result can be the improvement in the skill that they are doing it collaboratively (Benson, 2001; Naizhao \& Yanling, 2004; Pemberton \& Nix, 2012). The participants were asked to choose topics, and also raise some questions before starting to write.

As an example for practicing autonomy technique in class, the researcher brought some pictures to the class that they were related to each other. Each group of participants wrote a story for the pictures with the help of each other in groups. According to Khabiri and Lavasani (2012), picture storytelling, and the way it is taught (orienting autonomy) has some advantages such as increasing learners' pace of fluency in writing, enhancing learners' opportunity to work together which would promote autonomy, and stopping the learners being afraid of criticism or exposing themselves.

For elaborating some illustrations, as another example, the students brought some illustrations in books, magazines, and newspapers to the class and elaborated, and explained the illustrations in details in their writings. They were asked to write their personal feelings about pictures and also whatever that the pictures reminded them, made them feel or understood. They worked in groups of three afterwards, and helped each other to add some more information/ideas and also corrected their writings.

During the whole period of practicing autonomy, students rated the pieces of writing of their peers in their own groups, and gave a score that was copied in the teacher's (the researcher) classroom list by the students themselves. This motivated them to demonstrate the ability of being objective in their evaluation, and also they enjoyed being responsible for their own learning and evaluation as well as their friends'. In all sessions, teacher's feedback and scoring followed students' self-correction, self-assessment, peer-correction, and peer-assessment in order to improve the sense of autonomy in students.

Totally, they were asked to write eighteen pieces of writing in the class (one writing in each session), and six pieces of writing as their homework at home (one writing per week) during the research. The researcher spent about 30 minutes for practicing autonomy techniques at the beginning of each session.

At the end of the semester, the researcher administered the writing section of another version of a PET as a post-test to both groups of learners. The scores were obtained through the ratings by two raters, and finally the average score given by them to each participant was considered as the final score of each participant.

\section{RESULTS}

Initially, a PET sample was piloted on a group of 30 female EFL learners with similar characteristics to the target group, then the reliability of test was calculated through Cronbach alpha using SPSS program. The reliability of the PET turned out to be 0.7 .

TABLE 3.1

RELIABILITY OF PET

\begin{tabular}{|l|l|}
\hline & Reliability of the PET by Cronbach alpha \\
\hline PET & 0.7 \\
\hline
\end{tabular}


Based on the item analyses, five reading items were deleted.

In order to follow the purpose of the study, a Preliminary English Test (PET) was conducted among 100 students. The descriptive statistics of the PET used for homogenization is presented in the following table.

TABLE 3.2

DESCRIPTIVE STATISTICS OF PET USED FOR HOMOGENIZATION

\begin{tabular}{|l|l|l|l|l|l|l|l|l|}
\hline & $\mathrm{N}$ & Minimum & Maximum & Mean & Std. Deviation & \multicolumn{2}{|l|}{ Skewness } \\
\cline { 2 - 8 } & Statistic & Statistic & Statistic & Statistic & Statistic & Statistic & Std. Error \\
\hline PET scores & 100 & 19.00 & 93.00 & 55.0000 & 13.28552 & .157 & .241 \\
Valid N (listwise) & 100 & & & & & & \\
\hline
\end{tabular}

As shown above, the distribution of the scores was normal, as the skewness ratio was less than 1.96. The mean and the standard deviation turned out to be 55 and 13.28 respectively.

The inter-rater reliability of the scores given by the two raters to the PET writing scores at the piloting stage was ensured through calculating the correlation between the two sets of scores. The normality assumption was checked primarily.

TABLE 3.3

TESTS OF NORMALITY OF THE PET WRITING SCORES GIVEN BY THE TWO RATERS

\begin{tabular}{|l|l|l|l|l|l|l|}
\hline & \multicolumn{5}{l}{ Kolmogorov-Smirnov ${ }^{\mathrm{a}}$} & \multicolumn{3}{l|}{ Shapiro-Wilk } \\
\cline { 2 - 7 } & Statistic & Df & Sig. & Statistic & df & Sig. \\
\hline writing rater 1 & 144 & 30 & .116 & .930 & 30 & .048 \\
writing rater 2 & .180 & 30 & .014 & .929 & 30 & .045 \\
\hline
\end{tabular}

a. Lilliefors Significance Correction

As the above table depicts, by virtue of the Kolmogorov-Smirnov test one set of scores was not normally distributed as the sig value was less than .05 (.014), and both values on the Shapiro-Wilk test were less than .05. Therefore, the non-parametric Spearman correlation was used to calculate the correlation between them. The following table shows the result:

TABLE 3.4

CORRELATIONS BETWEEN PET WRITING SCORES GIVEN BY THE TWO RATERS

\begin{tabular}{|lll|l|l|}
\hline \multicolumn{2}{|c|}{ CORRELATIONS BETWEEN PET WRITING SCORES GIVEN BY THE TWO RATERS } \\
\hline Spearman's rho & writing rater 1 & Correlation Coefficient & writing rater 1 & writing rater 2 \\
& & Sig. (2-tailed) & .000 & $.675^{* *}$ \\
& $\mathrm{~N}$ & 30 & .000 \\
& & Correlation Coefficient & $.675^{* *}$ & 1.000 \\
\cline { 2 - 5 } & Sig. (2-tailed) & .000 &. \\
& $\mathrm{~N}$ & 30 & 30 \\
\hline
\end{tabular}

**. Correlation is significant at the 0.01 level (2-tailed).

As shown in the above table, there was a significant correlation between the two sets of scores $(r=.67, p=.000<.05)$. Therefore, the mean score for each pair was used for further calculations.

To check the inter-reliability between the scores given by the two raters on pre-treatment writings of both groups, Pearson correlation was conducted. But prior to that, the assumptions of linearity and normality were verified. The following table shows the descriptive statistics of the two sets of scores given by the two raters to the pre-treatment writings of the CT group.

At first, the descriptive statistics of the two raters' scores to the critical thinking group's pre-treatment writing scores was checked as the first assumption. The following table shows the result:

TABLE 3.5

DESCRIPTIVE STATISTICS OF THE RATERS' SCORES TO THE CT GROUP'S PRE-TREATMENT WRITING SCORES

\begin{tabular}{|l|l|l|l|l|l|l|}
\hline & $\mathrm{N}$ & Mean & Std. Deviation & \multicolumn{2}{|l|}{ Skewness } & Skewness Ratios \\
\cline { 2 - 7 } & Statistic & Statistic & Statistic & Statistic & Std. Error & \\
\hline CTpretestR1 & 37 & 19.3514 & 1.93242 & .031 & .388 & .07 \\
CTpretestR2 & 37 & 19.5946 & 1.80215 & -.283 & .388 & .72 \\
Valid N (listwise) & 37 & & & & & \\
\hline
\end{tabular}

As the table above shows, both skewness ratios are within the normality range of \pm 1.96 . Hence, both sets of scores were normally distributed. 
The following scatter plot shows the relationship between the two sets of scores:

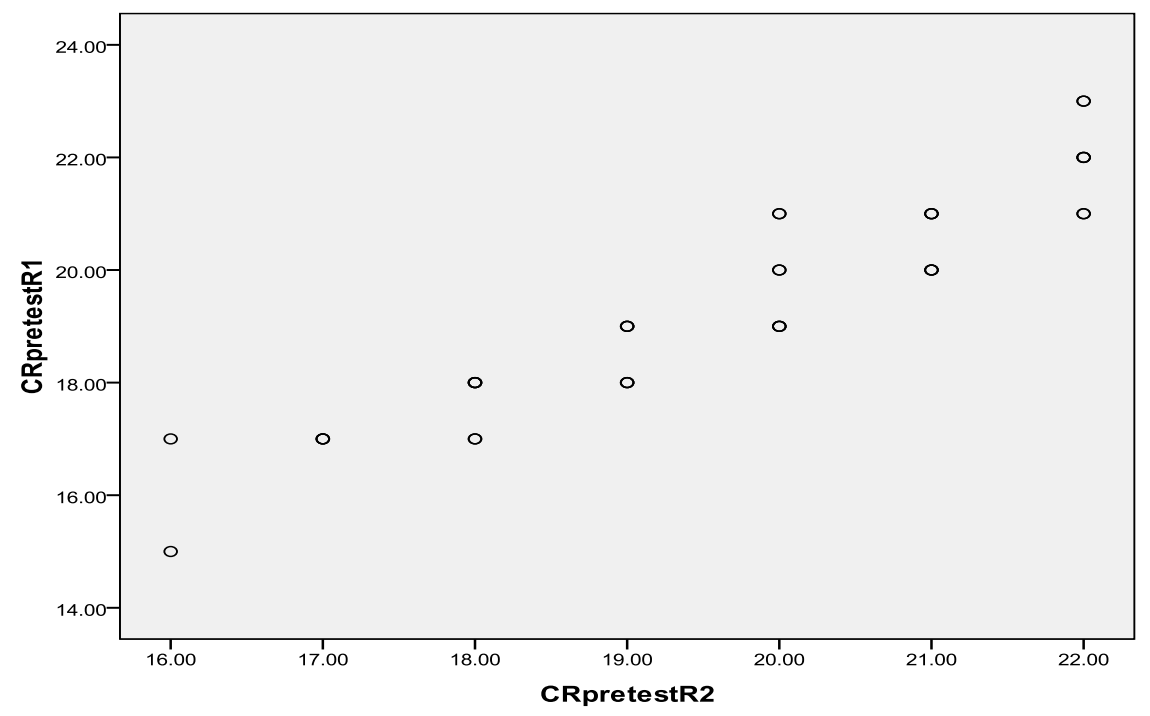

Figure 3.1 Scatter plot showing the relation between scores of the two raters on pretreatment writings of the CT group

As illustrated in the above figure, the dots form a linear shape. Thus, the linearity of the relationship is ensured. The following table shows the correlation coefficient between the two sets of scores:

TABLE 3.6

CORRELATION BETWEEN RATERS' SCORES TO CT GROUP'S PRE-TREATMENT WRITINGS

\begin{tabular}{|ll|l|l|}
\hline & & CRpretestR1 & CRpretestR2 \\
\hline CTpretestR1 & Pearson Correlation & 1 & $.935^{* *}$ \\
& Sig. (2-tailed) & 37 & .000 \\
& $\mathrm{~N}$ & 37 \\
\hline CTpretestR2 & Pearson Correlation & $.935^{* *}$ & 1 \\
& Sig. (2-tailed) & .000 & \\
& $\mathrm{~N}$ & 37 & 37 \\
\hline
\end{tabular}

As the above table depicts, the correlation between the two sets of scores given by the two raters turned out to be significant $(\mathrm{r}=.93, \mathrm{p}=.000<.05)$, hence the inter-rater reliability.

The same statistical procedure was followed for the pre-treatment writing scores of the autonomy group. The following table shows the descriptive statistics of the scores given by the two raters:

TABLE 3.7

DESCRIPTIVE STATISTICS OF THE RATERS' SCORES TO THE AUTONOMY GROUP'S PRE-TREATMENT WRITING SCORES

\begin{tabular}{|l|l|l|l|l|l|l|l|}
\hline & $\mathrm{N}$ & Minimum & Mean & Std. Deviation & \multicolumn{2}{l|}{ Skewness } & \multicolumn{2}{l|}{ Skewness Ratios } \\
\cline { 2 - 9 } & Statistic & Statistic & Statistic & Statistic & Statistic & Std. Error & \\
\hline AutpretestR1 & 37 & 14.00 & 19.2432 & 2.26575 & -.152 & .388 & -.39 \\
AutpretestR2 & 37 & 15.00 & 19.5405 & 2.04932 & -.051 & .388 & -.13 \\
Valid N (listwise) & 37 & & & & & & \\
\hline
\end{tabular}

As the above table shows, both skewness ratios are within the normality range of \pm 1.96 . Thus, both sets of scores were normally distributed. The following scatter plot exhibits the linearity of the relation. 


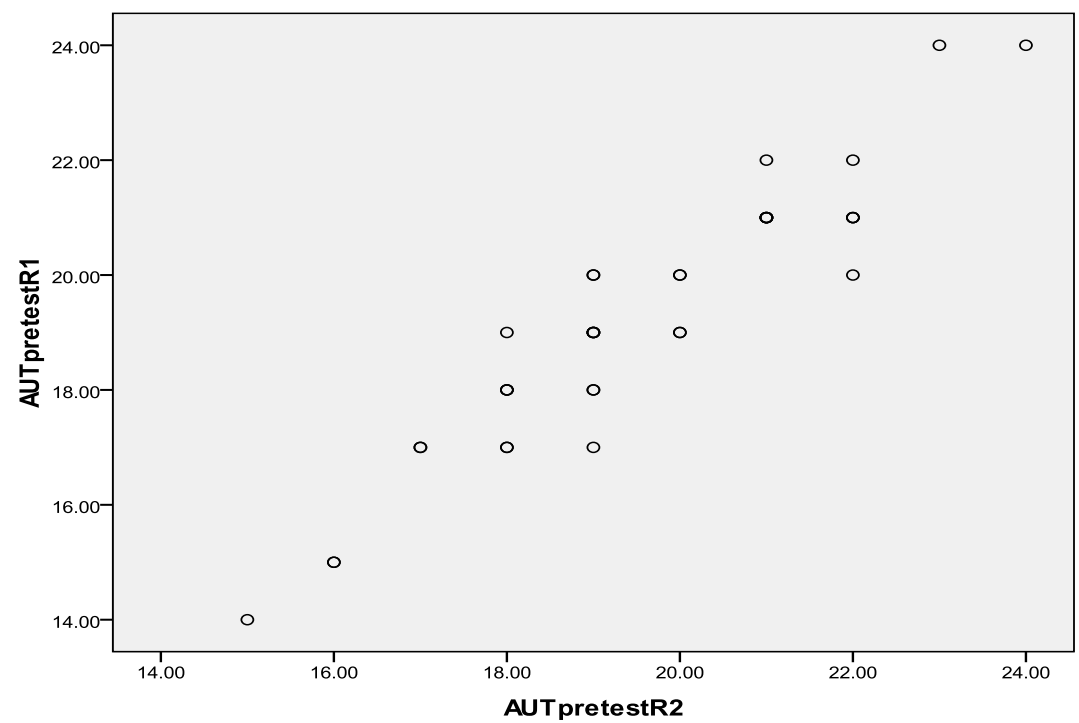

Figure 3.2 Scatter plot showing the relation between scores of the two raters on pretreatment writings of the autonomy group

As shows in the above figure, the points are scattered around a straight line, hence the linearity of the relation. The following table shows the result of the Pearson correlation analysis:

TABLE 3.8

\begin{tabular}{|c|c|c|c|}
\hline & & AUTpretestR1 & AUTpretestR2 \\
\hline \multirow[t]{3}{*}{ AUTpretestR1 } & Pearson Correlation & 1 & $.940^{* *}$ \\
\hline & Sig. (2-tailed) & & .000 \\
\hline & $\mathrm{N}$ & 37 & 37 \\
\hline \multirow[t]{3}{*}{ AUTpretestR2 } & Pearson Correlation & $.940^{* *}$ & 1 \\
\hline & Sig. (2-tailed) & .000 & \\
\hline & $\mathrm{N}$ & 37 & 37 \\
\hline
\end{tabular}

**. Correlation is significant at the 0.01 level (2-tailed).

The above table displays that the correlation between the two sets of scores was significant $(\mathrm{r}=.94, \mathrm{p}=.000<.05)$, thus the inter-rater reliability. Therefore, their mean scores could be safely used for the final calculations.

In order to ensure that the two groups were homogeneous regarding their writing ability prior to the treatment, a t-test was conducted. Primarily, though, the assumption of normality was checked through the following table showing the descriptive statistics of the scores which are the mean of the scores given by the two raters.

TABLE 3.9

DESCRIPTIVE STATISTICS OF THE PRE-TREATMENT WRITING SCORES

\begin{tabular}{|l|l|l|l|l|l|l|}
\hline & $\mathrm{N}$ & Mean & Std. Deviation & Skewness & Skewness Ratios \\
\cline { 2 - 7 } & Statistic & Statistic & Statistic & Statistic & Std. Error & \\
\hline CT pretreatment writing & 37 & 19.4730 & 1.83691 & -.136 & .388 & .35 \\
Autonomy pretreatment writing & 37 & 19.3919 & 2.12503 & -.126 & .388 & .32 \\
Valid N (listwise) & 37 & & & & & \\
\hline
\end{tabular}

As displayed in the above table, both distributions were normal as the skewness ratios of both sets of scores fell within the normality range. With this assumption met, the t-test was legitimate to use for comparing the mean scores. The following tables show the result of the t-test:

TABLE 3.10

GROUP STATISTICS OF THE PRETREATMENT WRITING SCORES

\begin{tabular}{|c|c|c|c|c|c|}
\hline & Grouping & $\mathrm{N}$ & Mean & Std. Deviation & Std. Error Mean \\
\hline \multirow[t]{2}{*}{ Pretreatment writing scores } & $\mathrm{CT}$ & 37 & 19.4730 & 1.83691 & .30199 \\
\hline & Autonomy & 37 & 19.3919 & 2.12503 & .34935 \\
\hline
\end{tabular}


The above table shows that the two groups performed very much similarly in the pre-treatment writing test obtaining mean scores of 19.47 and 19.39. The following table shows the independent samples test on the pre-treatment writing scores:

TABLE 3.11

INDEPENDENT SAMPLES TEST ON THE PRE-TREATMENT WRITING SCORES

\begin{tabular}{|c|c|c|c|c|c|c|c|c|c|c|}
\hline & & \multicolumn{2}{|c|}{$\begin{array}{l}\text { Levene's Test for } \\
\text { Equality of Variances }\end{array}$} & \multicolumn{7}{|c|}{ t-test for Equality of Means } \\
\hline & & \multirow[b]{2}{*}{$\mathrm{F}$} & \multirow[b]{2}{*}{ Sig. } & \multirow[b]{2}{*}{$\mathrm{t}$} & \multirow[b]{2}{*}{ df } & \multirow[b]{2}{*}{ Sig. (2-tailed) } & \multirow[b]{2}{*}{ Mean Difference } & \multirow[b]{2}{*}{$\begin{array}{l}\text { Std. Error } \\
\text { Difference }\end{array}$} & \multicolumn{2}{|c|}{$\begin{array}{l}\text { 95\% Confidence Interval } \\
\text { of the Difference }\end{array}$} \\
\hline & & & & & & & & & Lower & Upper \\
\hline \multirow[t]{2}{*}{$\begin{array}{l}\text { Pretreatment } \\
\text { writing } \\
\text { scores }\end{array}$} & $\begin{array}{l}\text { Equal } \\
\text { variances } \\
\text { assumed }\end{array}$ & .268 & .606 & .176 & 72 & .861 & .08108 & .46178 & -.83947 & 1.00163 \\
\hline & $\begin{array}{l}\text { Equal } \\
\text { variances } \\
\text { not } \\
\text { assumed }\end{array}$ & & & .176 & 70.524 & .861 & .08108 & .46178 & -.83980 & 1.00196 \\
\hline
\end{tabular}

As shown above, the difference between the mean scores of the two groups on the writing pre-treatment test turned out to be non-significant $(\mathrm{t}=.176, \mathrm{p}=.861>.05)$ with the equal variances condition assumed. Therefore, any possible difference in their posttest writing scores could reasonably be attributed to the treatment they received.

The inter-rater reliability of the scores given by the two raters to the posttest writing performances of the two groups was checked through Pearson correlation formula. The assumptions of normality and linearity were checked as appears hereunder:

TABLE 3.12

DESCRIPTIVE STATISTICS OF THE RATERS' SCORES TO THE CT GROUP’S POSTTEST WRITINGS

\begin{tabular}{|l|l|l|l|l|l|}
\hline & $\mathrm{N}$ & Mean & Std. Deviation & Skewness & \multicolumn{2}{|l|}{ Skewness Ratios } \\
\cline { 2 - 7 } & Statistic & Statistic & Statistic & Statistic & Std. Error \\
\hline CTposttesR1 & 37 & 20.4324 & 2.19267 & .263 & .388 \\
CTposttestR2 & 37 & 20.5135 & 2.11636 & .315 & .388 \\
Valid N (listwise) & 37 & & & & .81 \\
\hline
\end{tabular}

As, both skewness ratios, reported above, are within the normality range of \pm 1.96 , both sets of scores were normally distributed. The following graph shows the linearity of the relationship, as the second assumption for Pearson correlation formula.

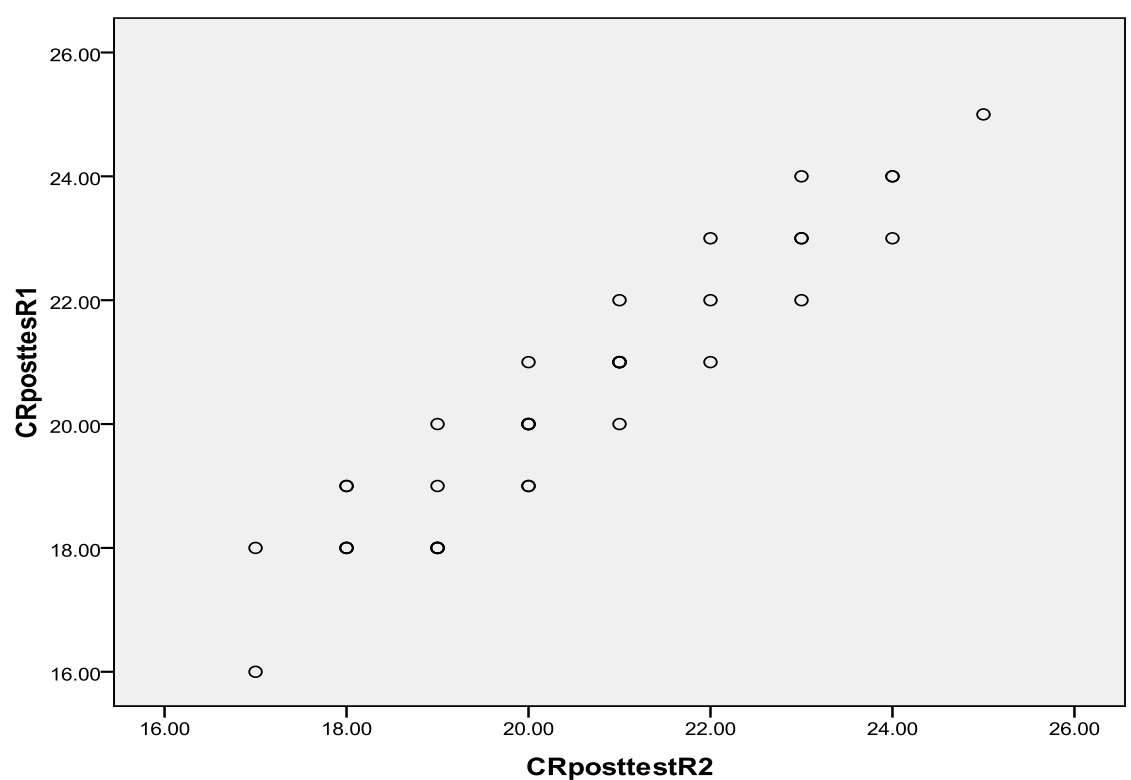

Figure 3.3 Scatter plot showing the relation between scores of the two raters to posttest writings of the CT group 
As exhibited above, the points are almost perfectly scattered around a line stretching from the bottom left to the top right; hence, linearity of the relation. With the assumptions met, the following Pearson correlation analysis was safely conducted:

TABLE 3.13

CORRELATIONS BETWEEN THE RATERS' SCORES TO CT GROUP'S POSTTEST WRITINGS

\begin{tabular}{|ll|l|l|}
\hline & & CRposttesR1 & CRposttestR2 \\
\hline CTposttesR1 & Pearson Correlation & 1 & $.944^{* *}$ \\
& Sig. (2-tailed) & 37 & .000 \\
& $\mathrm{~N}$ & 37 \\
\hline CTposttestR2 & Pearson Correlation & $.944^{* *}$ & 1 \\
& Sig. (2-tailed) & .000 & \\
& $\mathrm{~N}$ & 37 & 37 \\
\hline
\end{tabular}

**. Correlation is significant at the 0.01 level (2-tailed).

Depicted in the above table, the two sets of scores given by the two raters turned out to be significantly correlated $(\mathrm{r}=.94, \mathrm{p}=.000<.05)$. Therefore, the mean scores of each pair could safely be used for the final calculations.

As for the scores given to the posttest writings of the autonomy group, the inter-rater reliability check was implemented meeting the assumptions first. The normality condition was checked through the following analysis:

TABLE 3.14

DESCRIPTIVE STATISTICS OF THE RATERS' SCORES TO THE CT GROUP'S POSTTEST WRITINGS

\begin{tabular}{|l|l|l|l|l|l|l|}
\hline & $\mathrm{N}$ & Mean & Std. Deviation & Skewness & Skewness Ratios \\
\cline { 2 - 7 } & Statistic & Statistic & Statistic & Statistic & Std. Error & \\
\hline CTposttesR1 & 37 & 20.4324 & 2.19267 & .263 & .388 & .67 \\
CTposttestR2 & 37 & 20.5135 & 2.11636 & .315 & .388 & .81 \\
Valid N (listwise) & 37 & & & & & \\
\hline
\end{tabular}

As the skewness ratios are within the normality range of \pm 1.96 , it is concluded that the two sets of scores were normally distributed. The following graph shows the linearity of the relation as the second assumption:

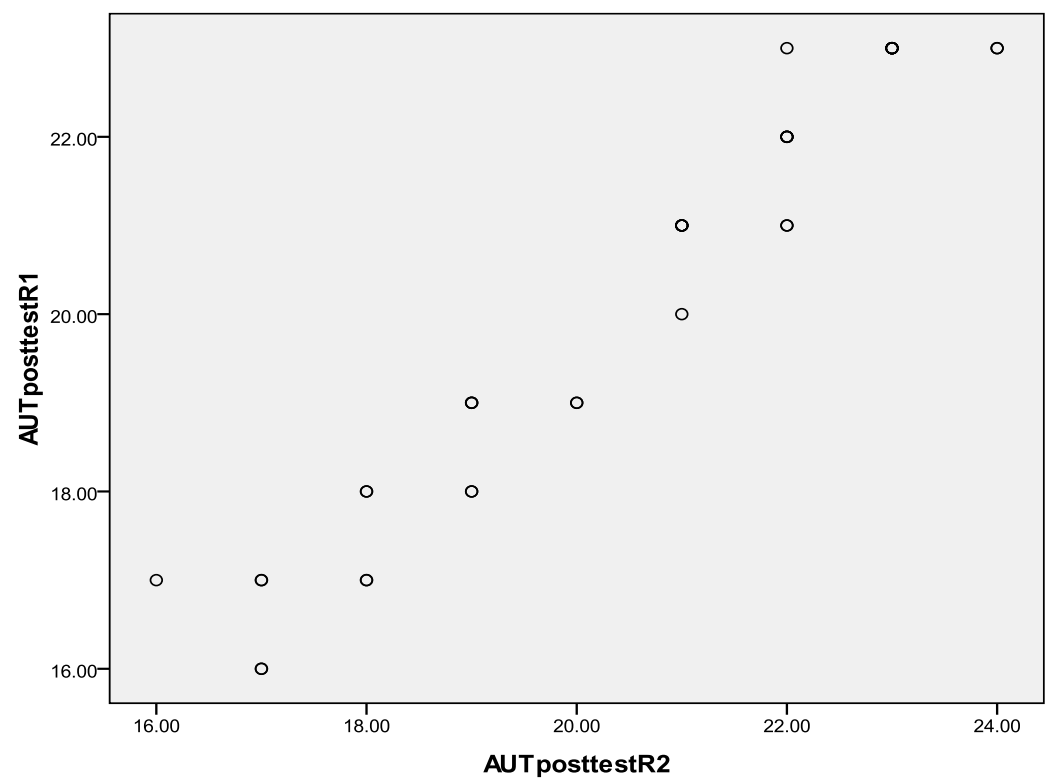

Figure 3.4 Scatter plot showing the relation between scores of the two raters on posttest writings of the autonomy group

As all the points, displayed in the above figure, evenly form an almost perfect linear shape, the linearity of the relation is ensured.

With the two conditions met, the Pearson correlation analysis was used to verify the inter-rater reliability as reported below: 
TABLE 3.15

CORRELATION BETWEEN RATERS' SCORES TO AUTONOMY GROUP'S POSTTEST WRITINGS

\begin{tabular}{|ll|l|l|}
\hline & & AUTposttestR1 & AUTposttestR2 \\
\hline AUTposttestR1 & Pearson Correlation & 1 & $.970^{* *}$ \\
& Sig. (2-tailed) & .000 \\
& $\mathrm{~N}$ & 37 \\
\hline AUTposttestR2 & Pearson Correlation & $.970^{* *}$ & 1 \\
& Sig. (2-tailed) & .000 & 37 \\
& $\mathrm{~N}$ & 37 & 37 (2-tailed). \\
\hline
\end{tabular}

**. Correlation is significant at the 0.01 level (2-tailed).

As shown in the above table, the two sets of scores given by the two raters were significantly correlated $(r=.97$, $\mathrm{p}=.000<.05)$. Therefore, their mean scores could safely be utilized for further calculations.

To check the significance of the difference between the posttest writing scores of the two groups, hence, testing the null hypothesis a t-test was conducted. Primarily, though, the assumption of normality was verified:

TABLE 3.16

DESCRIPTIVE STATISTICS OF THE POSTTEST WRITING SCORES

\begin{tabular}{|l|l|l|l|l|l|l|}
\hline & $\mathrm{N}$ & Mean & Std. Deviation & \multicolumn{1}{|l|}{ Skewness } & Skewness Ratios \\
\cline { 2 - 7 } & Statistic & Statistic & Statistic & Statistic & Std. Error & \\
\hline CTposttest & 37 & 20.4595 & 2.11928 & .339 & .388 & .87 \\
AUTposttest & 37 & 20.3108 & 2.29840 & -.269 & .388 & .69 \\
Valid N (listwise) & 37 & & & & & \\
\hline
\end{tabular}

As shown above, the two skewness ratios fell within the normality range. Thus, the two sets of scores were normally distributed; hence, the assumption was met.

Testing the Hypothesis

To test the null hypothesis of the study, hence to reveal any significant difference in the mean scores of the two groups on the posttest, an independent sample $t$ test was conducted. The following tables show the result:

TABLE 3.17

GROUP STATISTICS OF THE WRITING POSTTEST SCORES

\begin{tabular}{|ll|l|l|l|l|}
\hline & Grouping & N & Mean & Std. Deviation & Std. Error Mean \\
\hline \multirow{2}{*}{ writing posttest scores } & CT & 37 & 20.4595 & 2.11928 & .34841 \\
& autonomy & 37 & 20.3108 & 2.29840 & .37786 \\
\hline
\end{tabular}

As it is displayed in the above table, the two groups gained very similar means on the posttest (20.45 vs. 20.31). The following table tests the statistical significance of the small difference.

TABLE 3.18

INDEPENDENT SAMPLES TEST ON THE WRITING POSTTEST SCORES

\begin{tabular}{|c|c|c|c|c|c|c|c|c|c|c|}
\hline & \multicolumn{2}{|c|}{$\begin{array}{l}\text { Levene's Test for } \\
\text { Equality of Variances }\end{array}$} & \multicolumn{7}{|c|}{ t-test for Equality of Means } \\
\hline & & \multirow[b]{2}{*}{$\mathrm{F}$} & \multirow[b]{2}{*}{ Sig. } & \multirow[b]{2}{*}{$\mathrm{t}$} & \multirow[b]{2}{*}{ Df } & \multirow[b]{2}{*}{\begin{tabular}{|l|} 
Sig. \\
(2-tailed)
\end{tabular}} & \multirow[b]{2}{*}{\begin{tabular}{|l} 
Mean \\
Difference
\end{tabular}} & \multirow[b]{2}{*}{$\begin{array}{l}\text { Std. Error } \\
\text { Difference }\end{array}$} & \multicolumn{2}{|c|}{$\begin{array}{l}95 \% \text { Confidence Interval of } \\
\text { the Difference }\end{array}$} \\
\hline & & & & & & & & & Lower & Upper \\
\hline \multirow{2}{*}{$\begin{array}{l}\text { writing } \\
\text { posttest } \\
\text { scores }\end{array}$} & $\begin{array}{l}\text { Equal variances } \\
\text { assumed }\end{array}$ & 1.219 & .273 & .289 & & & .14865 & .51397 & -.87593 & 1.17322 \\
\hline & $\begin{array}{l}\text { Equal variances } \\
\text { not assumed }\end{array}$ & & & .289 & 71.531 & .773 & .14865 & .51397 & -.87604 & 1.17334 \\
\hline
\end{tabular}

As shown in the above table, with the equality of the variances assumed, the difference between the two mean scores turned out to be non-significant $(\mathrm{t}=.289, \mathrm{p}=.773>.05)$. The conclusion; therefore, is that the null hypothesis fails to be rejected implying that the two treatments were equally effective in writing achievement of the learners.

\section{Discussions AND CONCLUSIONS}

Totally, the analyses of the data reported in this study revealed that there was no significant difference between the impact of autonomy and critical thinking on EFL learners' writing achievement. This is to say, autonomy and critical thinking techniques were equally effective on the learners' writing achievement. 
The justification of the findings of the present study can be traced through the work and observations of other theoreticians and researchers. Atkinson (1997) for example believes that a critical thinker is someone who is "truth-seeking, open-minded, analytical, systematic, self-confident, inquisitive, and mature" that are believed as effective features for learners in order to achieve the goal of language learning in the best way possible. Critical thinking is considered a special method because it tries to make learners discover different concepts not to teach them those concepts directly which leads learners to keep them in their minds permanently, and be active learners all the time (Gorjian, Pazhakh, \& Parang, 2012).

The finding of this study related to the equally positive effect of autonomy on writing ability of learners may be justified through the fact that improving the autonomy in learners means to motivate students "to determine the objectives, to define the contents and progressions, to select methods and techniques to be used, to monitor the procedures of acquisition and to evaluate what has been acquired" (Holec, 1981, p. 3). During this process, the autonomous learner determines "a personal agenda for learning" (Little, 1994; Chan, 2003) by making directions in the "planning, pacing, monitoring, and evaluating the learning process" (Balçıkanlı 2010, p.90). It is believed that if students are "involved in decision making processes regarding their own language competence" (Balç1kanlı 2010, p.90), "they are likely to be more enthusiastic about learning" (Littlejohn, 1985, p. 258), and learning can be more focused and purposeful for them (Chan, 2001, 2003).

Little (1990) presents learner autonomy as a matter of psychological reaction that learners show to the procedure and content of learning, so autonomy provides a chance for learners to choose and follow the best learning strategies to learn in the best way at their own pace (Balçıkanl1 2010). Writing, therefore, is one of the skills that has shown to benefit from all these positive features of autonomy.

\section{Pedagogical Implications}

\section{A. Implications for EFL Teachers}

At the present time, training students who are autonomous and critical thinkers is a great necessity for the society, because of the great changes in academic requirements, so many recent studies focus on the growing interest in autonomy, critical thinking, and their effects on language learning (Ming \& Alias, 2003). "Criticality and learner autonomy are both widely seen as desirable educational goals, and often understood as independent or even mutually indispensable attributes" (Nix \& Pemberton, 2012). According to Lamb, Raya, and Vieira (2007), "The competence to think critically is coextensive with the notion of autonomy" (p.43).

Regarding the findings of the present study, autonomy and critical thinking both have positive impact on EFL learners' improvement. The result has some implications for EFL teachers to acquaint the learners with the techniques mentioned. The teachers are suggested to implement autonomy and critical thinking techniques as useful elements in their teaching to improve writing achievement of the learners. Actually, the findings of this study can help teachers to improve their instructions implementing useful techniques for teaching different skills specially writing, and making their students more active and interested in learning.

Accordingly, the findings can give bright insights to teachers to pave the way for their students to improve themselves by the mentioned techniques, and teaching them to think critically and act autonomously. The findings of the present study can be used as a guide to both teachers and learners to accelerate the outcome of their EFL classes.

\section{B. Implications for Learners}

Language learning is considered as complex phenomenon that includes various dimensions; therefore, not only language teachers, but also language learners, syllabus designers, and material developers have great roles in paving the way to facilitate this complex process.

In the past, teachers had the greatest role in classes, but gradually they are changing their traditional roles and they are moving to new roles; that is, they are trying to act as consultants, guides, and monitors in the classes. In addition, at the same time, they try to encourage their students to develop better techniques for learning and to act more independently (Murphey, 2008); therefore, the results of the current study has great implications for learners to move from traditional learning context to the modern one, and try to act more independently and autonomously in the complicated process of learning a new language.

As a result, the findings of the current study have implications for language learners in order to encourage them to become autonomous and critical thinkers not only in educational contexts of language learning, but also in their personal and social lives. Therefore, improving autonomy and critical thinking in an educational context for learning a new language empowers them to implement autonomous and critical activities to have a higher writing ability.

\section{Implications for Syllabus Designers and Material Developers}

The study can also provide some clues for the materials developers who attempt their best to provide the most effective, useful, fertile, and encouraging materials with autonomy and critical thinking orientation in the EFL learning context. In this regard, materials developers are expected to implement the tasks in EFL materials in such a way that criticality, independence, and confident grow up in language learners drastically. It is worth to state that regarding the multidimensional phenomenon of language learning, some essential points appear inevitable for materials developers. 
Materials developers and syllabus designers are expected to act in their closest cooperation with language teachers. Curriculum designers can consider enough time and tasks for teachers to familiarize the students with the mentioned techniques of this study and help them to nurture these techniques in their learning procedure. On the other hand, cooperation of materials developers and curriculum designers with teachers can be of great use in order to create materials which are congruent with the level of autonomy and criticality of the students in different levels of language learning.

\section{Suggestions for Further Research}

The subsequent recommendations are presented with the hope that other researchers would find them interesting and useful enough to pursue in the future.

1. This study was conducted on the EFL learners between the age of 22-35. Considering the differences among different age groups regarding the mental and personal qualities, the same study could be conducted among other age groups.

2. This study was conducted among female EFL learners. It is recommended that the same study be replicated among male EFL learners in order to see if the same results are achieved.

3. Other studies can be conducted by the researchers to find out the comparative impact of autonomy and critical thinking techniques on the other language skills.

4. Other studies may be carried out to see if autonomous techniques of teaching have any impact on critical thinking ability of the learners.

\section{REFERENCES}

[1] Al-Hazmi, S. (2006). Writing and Reflection: Perceptions of Arab EFL Learners. South Asian Language Review, 16(2), 36-52.

[2] Atkinson, D. (1997). A critical approach to critical thinking in TESOL. TESOL Quarterly, 31(1), 71-91.

[3] Bagheri, M \& Aeen, L. (2011). The Impact of Practicing Autonomy on the Writing Proficiency of Iranian Intermediate EFL Learners. Pan-Pacific Association of Applied Linguistics, 15(1), 1-13.

[4] Balcikanli, C. (2010). Learner Autonomy In Language Learning: Student Teachers' Beliefs. Australian Journal of Teacher Education, 35(1), 90-103.

[5] Benson, P. (2001). Teaching and Researching Autonomy in Language Learning. Lonsdon: Longman.

[6] Chaffee, J. (2009). Thinking critically. Journal of Marketing Education, 27(3), 264-276.

[7] Chan, V. (2001). Readiness for learner autonomy: What do our learners tell us? Teaching in Higher Education, 6(4), 505-519.

[8] Chan, V. (2003). Autonomous language learning: The teachers' perspectives. Teaching in Higher Education, 8(1), 33-54.

[9] Dewey, J. (1982). How We Think. Lexington, Mass: Heath (Originally published in 1910).

[10] Gorjian, B., Pazhakh, A., \& Parang, K. (2012). An Investigation on the Effect of Critical Thinking (CT) Instructions on Iranian EFL Learners' Descriptive Writing: A Case of Gender Study. Advances in Asian Social Science, 1(1), 114-118.

[11] Halpern, D. F. (1996). Thought and knowledge: An introduction to critical thinking (Third edition). New Jersey: Mahwa.

[12] Harmer, J. (2001). The practice of English language teaching. (3rd edn.). London: Pearson Education.

[13] Hedge, T. (2000). Teaching and learning in the language classroom. Oxford: Oxford University Press.

[14] Holec, H. (1981). Autonomy and Foreign Language Learning. Oxford: Pergamon.

[15] Khabiri, M. \& Lavasani, M. (2012). A Collaborative Approach to Autonomy: Does it Improve EFL Learners' Oral Proficiency? World Applied Sciences Journal, 20(9), 1293-1299.

[16] Kumaravadivelu, B. (2003). Beyond methods. Macrostrategies for language teaching. New Haven: Yale University Press.

[17] Little, D. (1990) ‘Autonomy in language learning’. In Ian Gathercole (ed.) Autonomy in Language Learning. London: CILT, pp. 7-15.

[18] Little, D. (1991). Learner Autonomy 1: definitions, issues and problems. Dublin: Authentik.

[19] Little, D. (1994). Learner autonomy: A theoretical construct and its practical application. Die Neuere Sprache, 93(5), 430-442.

[20] Littlejohn, A. (1985). Learner choice in language study. ELT Journal, 39(4), 253-261.

[21] Mangel, S. (2005). Advanced educational psychology (2nd ed.). New Delhi: Prentice-Hall of India.

[22] Marashi, H., \& Jafari, R. (2012). The Comparative Effect of Using Critical Thinking, Constructivist Learning, and a Combination of the Two Techniques on EFL Learners' Writing. Iranian EFL Journal, 8(4), 206-225.

[23] Ming, S., \& Alias, A. (2010). Investigating Readiness for Autonomy. A Comparison of Malaysian ESL Undergraduates of Three Public Universities. Reflections on English Language Teaching, 6(1), 1-18.

[24] Murphy, L. (2008). Supporting learner autonomy: Developing practice through the production of courses for distance learners of French, German, and Spanish. Language Teaching Research, 12(1), 1-2.

[25] Naizhao, G. \& Yanling, Zh. (2004). An Empirical Investigation of Learner Autonomy In Some EFL Classes in China, pp. 1-17. Shanxi University of Finance and Economics.

[26] Nation, I. S. P. (2001). Teaching and learning vocabulary in another language. Cambridge: Cambridge University Press.

[27] Paul, R. W., \& Elder, L. (2006). Critical thinking: The nature of critical and creative thought. Journal of Developmental Education, 30(2), 34-35.

[28] Pemberton, R., \& Nix, M. (2012). Practices of Critical Thinking, Criticality, and Learner Autonomy. Special Issue of Learning, 19(2), 79-95.

[29] Raya, M. J., Lamb, T., \& Vieira, F. (2007). Pedagogy for autonomy in language education in Europe: Towards a framework for learner and teacher development. Dublin: Authentik.

[30] Richards, J. C. (1990). The language teaching matrix. Cambridge: Cambridge University Press.

[31] Santrock, J. W. (2008). Educational psychology (3rd ed.). New York: Mac Graw Hill. 
[32] Shangarffam, N., \& Mamipour, M. (2011). The Impact of Teaching Critical Thinking on Intermediate EFL Learners' Writing Skill. American Journal of Scientific Research, 40, 119-125.

[33] Thornbury, S. (2005). How to teach speaking. London: Longman.

[34] Triastuti, A. (2006). Incorporating argumentation study for teaching critical thinking in EFL instruction: A proposal for EFL curriculum, pp. 1-14. Universitas Negeri Yogyakarta.

[35] WU Li-li. (2008). On cultivation of learner autonomy in EFL classroom. Hong Kong: Oxford University Press.

Behdokht Mall-Amiri was born in Iran in 1970. She obtained her Ph.D. in TEFL. She is currently teaching at Islamic Azad University at Central Tehran. Her major interests are linguistics, practical teaching, and material development courses.

Fatemeh Sheikhy was born in 1981, and obtained her B.A. in English Translation from Karaj Azad University. She pursued her education at Islamic Azad University at Central Tehran, and obtained M.A. in TEFL. She is currently teaching English to adults at various language schools in Karaj, Tehran, Iran.

Serving as an English teacher, she has taught at Zaban Sara Language School, Apadana Language School, Safir Mehr Language School, Rahmani Language School, Iranmehr Language School, and Kish Way Language School. 